\begin{tabular}{|c|c|c|}
\hline & International Journal of Current Research in & \\
\hline & Biosciences and Plant Biology & \\
\hline $\begin{array}{l}\text { EX } \\
\text { PUBL }\end{array}$ & $\begin{array}{c}\text { ISSN: 2349-8080 (Online) • Volume } 3 \bullet \text { Number } 3 \text { (March-2016) } \\
\text { Journal homepage: www.ijcrbp.com }\end{array}$ & \\
\hline
\end{tabular}

\title{
Isolation and Characterization of Soil Microorganisms for Potential Biocontrol Activity
}

\author{
S. Dhiva ${ }^{1}$, H. P. Jaishanker Pillai ${ }^{2 *}$, Venkat M. Shinde ${ }^{3}$ \\ ${ }^{1}$ Department of Microbiology, Sree Narayana College, Alathur, Palakkad, Kerala-678 541, India \\ ${ }^{2}$ Department of Microbiology, Gulbarga University, Kalaburagi, Karnataka-585 106, India \\ 3 Department of Botany, Gulbarga University, Kalaburagi, Karnataka-585 106, India
}

*Corresponding author.

\begin{tabular}{|c|c|}
\hline Abstract & Article Info \\
\hline $\begin{array}{l}\text { Biological control of pests is one of the important means for checking pest problems in } \\
\text { tomato. Biopesticides include living organisms which can destroy pests. Use of } \\
\text { biopesticides is one of the most appropriate and promising methods of pest } \\
\text { management. A better alternative to chemicals are the soil microbes such as } \\
\text { Trichoderma, Penicillium, etc., residing in the rhizosphere of crop plants that have the } \\
\text { ability to suppress the pathogens. Successful biological control systems commonly } \\
\text { employ naturally occurring, antagonistic microorganisms that are able to reduce the } \\
\text { activities of plant pathogens. Such antagonists (or biocontrol agents) can compete with } \\
\text { pathogens for nutrients, inhibit pathogen growth by secreting antibiotics, or reduce } \\
\text { pathogen populations through parasitism. So the native organisms were isolated from } \\
\text { the root section and soil of the tomato plants from various regions of Palakkad District, } \\
\text { where identified by growing it in specific media. In the study various bacteria such as } \\
\text { Lactobacilli, Pseudomonas, Cornyebacterium, Flavobacterium, Aeromonas, } \\
\text { Staphylococcus, Streptococcus, Serratia and fungi such as Aspergillus niger, } \\
\text { Aspergillus flavus, Cladosporium, Mucor, Trichophyton and Fusarium sp. were isolated. }\end{array}$ & $\begin{array}{l}\text { Ke y w o r d s } \\
\text { Antagonists } \\
\text { Biological control } \\
\text { Biopesticides } \\
\text { Rhizosphere }\end{array}$ \\
\hline
\end{tabular}

\section{Introduction}

Biological control of pests is one of the important means for checking pest problems in tomato. Biopesticides include living organisms which can destroy pests. Use of biopesticides is one of the most appropriate and promising methods of pest management (Hyakumachi et al., 1994). A better alternative to chemicals are the soil microbes such as Trichoderma, Penicillium, etc., residing in the rhizosphere of crop plants that have the ability to suppress the pathogens (Hyakumachi et al., 1994). Successful biological control systems commonly employ naturally occurring, antagonistic microorganisms that are able to reduce the activities of plant pathogens. Such antagonists (or biocontrol agents) can compete with pathogens for nutrients, inhibit pathogen growth by secreting antibiotics, or reduce pathogen populations through parasitism (Dubey et al., 2007). Fungal species belonging to the genus Trichoderma are worldwide in occurrence and easily isolated from soil, decaying wood, and other forms of plant organic matter.

The potential of Trichoderma species as biocontrol agents of plant diseases was first recognized in the early 1930s and in subsequent years, control of many diseases has been added to the list This has culminated in the commercial production of several Trichoderma species for the protection and growth enhancement of a number of crops in the United States and in the production of Trichoderma species and mixtures of species in India, 
Israel, New Zealand, and Sweden (Elad et al., 1980). Metabolites of Trichoderma harzianum, T. viride and T. virens have been found to inhibit the mycelial growth of Fusarium oxysporum (Dubey et al., 2007). The present study focuses the isolation and characterization of microbes with biocontrol potential.

\section{Materials and methods}

\section{Collection of soil samples from agricultural field and rhizosphere}

Soil samples were collected from various sources such as Agricultural field and Rhizosphere region from three locations namely Chittur, Kozhinjampara and Nemmara region, belonging to Palaghat District of Kerala State.

\section{Sterilization techniques}

The polyethylene bags used for Collection of samples were cold-sterilized in UV-radiation box for at least $12 \mathrm{~h}$, while glassware was treated in the hot-air oven at $160^{\circ} \mathrm{C}$ for $2 \mathrm{~h}$. Growth media and diluents (distilled water) were autoclaved at $121^{\circ} \mathrm{C}$ for $15 \mathrm{~min}$.

\section{Sampling}

The soil samples used for this work were collected from 3 different locations in Kerala. Soil and roots were collected from established tomato field plots that had been planted with tomatoes for at least two consecutive years. The samples were labeled according to the site of collection as CTR - Chittur samples, KJR Kozhinjampara samples, NEM - Nemmara samples. The samples were transported in polyethylene bags in ice pack to the laboratory.

\section{Determination of soil pH}

Soil $\mathrm{pH}$ was determined according to the procedure described by Akpor et al. (2006). Standardize the $\mathrm{pH}$ meter by means of the standard solutions provided. Immediately before immersing the electrode(s) into the sample, stir the sample well with a glass rod. Place the electrode(s) into the soil slurry solution and gently turn beaker to make good contact between the solution and the electrode(s).

\section{Isolation of microorganisms from root section}

Segments of root systems collected directly from the field also were used. Root sections of approximately 0.2 $\mathrm{g}$ were added to $100 \mathrm{ml}$ sterile water in flasks and shaken on a rotary shaker at $150 \mathrm{rpm}$ for $30 \mathrm{~min}$. Root segments, as well as a 10-fold dilution series of the resulting water suspensions, were plated on various general and selective media to recover root organisms.

For the isolation and characterization of bacterial isolates of interest, Cetrimide agar and CT- Agar were used (Allen and Conger, 1968; Altemeier et al., 1969) and identification of isolates was based on cultural, microscopic, and biochemical characteristics with reference to Bergey's Manual of Determinative Bacteriology (1989) for bacteria, and Talbot (1978) for fungi.

\section{Isolation of Trichoderma (Watts et al., 1988)}

Soil samples collected from different agricultural fields were inoculated onto potato dextrose agar (PDA), malt extract agar, rose bengal agar (MRBA) and oat flour agar and incubated at $28 \mathrm{C}$ for 5 days.

\section{Isolation of Fusarium (Ogunmwonyi, 2008)}

The tomato plant roots were collected under aseptic condition and root pieces $(2 \mathrm{~cm})$ of different diameter were transferred to flasks containing $100 \mathrm{ml}$ of sterilized distilled water. The flasks were shaken vigorously with the help of a shaker to get a homogenous suspension of the rhizosphere soil. Taking this as the stock solution, conventional soil dilution plate method was followed for isolation of the Rhizosphere fungi. Using potato dextrose agar medium and all the inoculated plates were then incubated at $25 \pm 2^{\circ} \mathrm{C}$. Identification of isolates was based on cultural, microscopic, and biochemical characteristics with reference to Talbot (1978) for fungi.

\section{Results and discussion}

The $\mathrm{pH}$ range in the root soil was almost neutral in all the three study sites (Table 1). The $\mathrm{pH}$ of 7.0, 7.5 and 7.2 was determined in the root soil collected from Chittur, Kozhinjampara and Nemmara respectively. The presence and absence of important genera of aerobic heterotrophic bacteria and fungi in root section are given in Table 2 and Table 3.

Table 1. Determination of $\mathrm{pH}$ from root soil.

\begin{tabular}{llll}
\hline Root soil & Chittur & Kozhinjampara & Nemmara \\
\hline Denomination & Neutral & Neutral & Neutral \\
pH & 7.0 & 7.5 & 7.2 \\
\hline
\end{tabular}


Table 2. Isolation of microorganisms from root section Occurrence and abundance of some genera of aerobic heterotrophic bacteria in root section.

\begin{tabular}{llll}
\hline \multirow{2}{*}{ Bacteria } & \multicolumn{3}{l}{ Occurrence } \\
\cline { 2 - 4 } & Chittur & Kozhinjampara & Nemmara \\
\hline Lactobacillus & + & - & + \\
Bacillus & + & + & + \\
Pseudomonas & + & + & + \\
Corynebacterium & - & + & + \\
Flavobacterium & + & + & + \\
Aeromonas & + & + & + \\
Staphylococcus & - & + & - \\
Serratia & + & + & + \\
Streptococcus & + & + & + \\
\hline
\end{tabular}

Note:- (+) indicates presence of a particular species; (-) indicates absence of a particular species.

Table 3. Occurrence and abundance of some genera of aerobic heterotrophic fungi in root section.

\begin{tabular}{llll}
\hline \multirow{2}{*}{ Fungi } & \multicolumn{3}{l}{ Occurrence } \\
\cline { 2 - 4 } & Chittur & Kozhinjampara & Nemmara \\
\hline Aspergillus niger & + & + & + \\
Aspergillus flavus & + & + & + \\
Cladosporium sp. & + & + & + \\
Penicillum sp. & + & + & + \\
Mucor mucedo & + & + & + \\
Trichophyton sp. & + & + & + \\
Fusarium sp. & + & + & - \\
Microsporium sp. & + & + & + \\
\hline
\end{tabular}

Note:- (+) indicates presence of a particular species; (-) indicates absence of a particular species.

Citrimide agar plates were examined for the presence of characteristic blue, blue-green, or yellow-green pigment. Pseudomonas typically produces both pyocyanin and fluorescein.

\section{Characterization of fungal isolates}

Growth on selective media -Trichoderma harzianum (Fig. 1): The growth rate was rapid and colonies were woolly becoming compact in time. The surface colony colour was found to be white and scatters greenish patches became visible as the conidia developed. The colour was pale yellowish. Microscopic appearance showed the presence of septate hyaline hyphae, conidiophores, phialides and conidia. The phialides were hyaline, branched, flask-shaped, inflated at the base, solitary and appeared in clusters and were attached to the conidiophores at right angles. The conidiophores were hyaline, branched and occasionally arranged in pyramidal shape. The conidia were unicellular, round, green in colour, smooth walled, with an average diameter of $3 \mu \mathrm{m}$, and are grouped in sticky heads at the tip of the phialides.

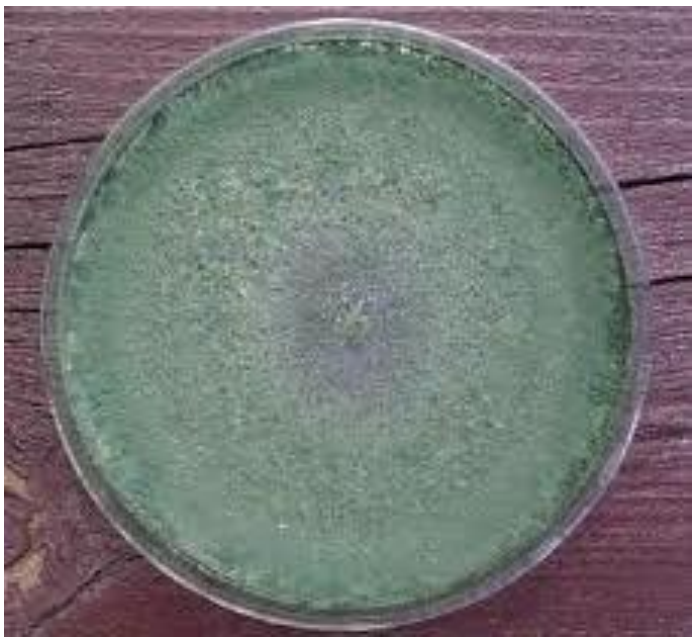

Fig. 1: Macroscopic appearance of Trichoderma harzianum.

From the soil when the $\mathrm{pH}$ was analysed, it was almost alkaline in all the three regions of Palakkad District, Kerala. Similarly from the root section various bacteria such as Lactobacilli, Pseudomonas, Cornyebacterium, Flavobacterium, Aeromonas, Staphylococcus, Streptococcus, Serratia were isolated and fungi such as Aspergillus niger, Aspergillus flavus, Cladosporium, Mucor, Trichophyton, Fusarium sp. were isolated, they were identified by using various biochemical tests on the basis of Bergeys Manual. These isolated organisms may be pathogenic to the plant or may be antagonistic against the pathogenic microorganism, but repeated use of pesticides totally alters the soil environment thereby changing the soil $\mathrm{pH}$, nature and fertility of the soil.

This finding was supported by Rowe and Farley (1981), stated that Fusarium oxysporum f. radicis lycopersici is an important and wide spread vascular wilt pathogen of tomato. For many years control of Fusarium crown and root rot of tomato has been limited to the use of conventional soil sterilizing procedures together with the application of fungicides. Similarly, Yigit and Dikillitas (2007) stated that Pseudomonas fluorescens bacterial suspension was found to be effective in reducing the tomato wilt under greenhouse conditions when applied as a seed treatment. This may have been due to their ability to inhibit the growth of $F$. oxysporum in the rhizosphere. Based on these findings these isolated microorganisms can be screened for their potential biocontrol activity against the pathogens of tomato wilt.

\section{Conclusion}

Various bacteria and fungi were isolated from the root region of the tomato plant, these organisms includes the pathogens and commensals of the plant. Repeated use of 
fungicides and bactericides totally alters the soil nature including the $\mathrm{pH}$, fertility, and natural flora of the soil. So further study is required to be made to check the ability of certain microorganisms as a potential biocontrol agent to control the wilt diseases of tomato.

\section{Conflict of interest statement}

Authors declare that they have no conflict of interest.

\section{References}

Akpor, O.B., Okoh, A.I., Babalola, G.O., 2006. Cultural microbial population dynamic dur ing decomposition of Theobroma cacao leaf litters in a tropical soil setting. J. Bio. Sci. 6 (4), 768-774.

Bergey's Manual of Systematic Bacteriology, 1989. (Eds.: Williams, S.T., Sharpe, M.E., Holt, J.G.) Williams and Wilkins, Baltimore.

Dubey, S.C., Suresh, M., Singh, B., 2007. Evaluation of Trichoderma species against Fusarium oxysporum f.sp. ciceris for integrated management of chickpea wilt. Biol. Cont. 40, 118-127.
Elad, Y., Chet, I., Katan, J., 1980. Trichoderma harzianum: A biocontrol agent of Sclerotium rolfsii and Rhizoctonia solani. Phytopathol. 70, 119-121.

Hyakumachi, M., 1994. Plant-growth-promoting fungi from turf grass rhizosphere with potential for disease suppression. Soil Microorg. 44, 53-68.

Ogunmwonyi, I. N., Igbinosa, O. E., Aiyegoro, O. A., Odjadjare, E., 2008. Microbial analysis of different top soil samples of selected site in Obafemi Awolowo University, Nigeria. Scient. Res. Essay 3(3), 120-124.

Rowe, R.C., Farley, J.D., 1981. Strategies for controlling Fusarium crown and root rot in green house tomatoes. Plant Dis. 55, 105-112.

Talbot, P.H.B., 1978. Principles of Fungal Taxonomy. MacMillan Press. 274p.

Watts, R., Dahiya, J., Chaudhary, K., Tauro, P., 1988. Isolation and characterization of a new antifungal metabolite of Trichoderma reesei. Plant Soil 107, 81-84.

Yigit, F., Dikillitas, M., 2007. Control of Fusarium wilt of tomato by combination of fluorescent Pseudomonas, nonpathogen Fusarium and Trichoderma harzianum T-22 in green house conditions. Plant Pathol. J. 4(2), 91-95.

\section{How to cite this article:}

Dhiva, S., Jaishanker Pillai, H.P., Shinde, V. M., 2016. Isolation and characterization of soil microorganisms for potential biocontrol activity. Int. J. Curr. Res. Biosci. Plant Biol. 3(3), 26-29. doi: http://dx.doi.org/10.20546/ijcrbp.2016.303.005 